\title{
PENGARUH KARAKTERISTIK DEMOGRAFIS DAN LITERASI KEUANGAN TERHADAP KEPUTUSAN INVESTASI MELALUI BEHAVIORAL BIASES
}

\author{
Feshia Natalia dan Hendra Wiyanto \\ Program Studi Manajemen, Universitas Tarumanagara Jakarta \\ Email: feshia.115170137@stu.untar.ac.id
}

\begin{abstract}
Abstrak: Penelitian ini bertujuan untuk mengetahui pengaruh karakteristik demografis dan literasi keuangan terhadap behavioral biases dan keputusan investasi pada investor saham, serta mengetahui pengaruh behavioral biases terhadap keputusan investasi dan peran behavioral biases dalam memediasi karakteristik demografis dan literasi keuangan terhadap keputusan investasi investor saham. Desain penelitian yang digunakan dalam penelitian ini adalah penelitian deskriptif dengan pendekatan kuantitatif. Teknik pengambilan sampel menggunakan metode nonprobability sampling yaitu purposive sampling. Metode pengumpulan data menggunakan kuesioner dan diperoleh sampel berjumlah 103 responden. Teknik analisis data menggunakan Partial Least Square, dengan sotfware SmartPLS. Hasil penelitian menunjukkan bahwa karakteristik demografis, literasi keuangan dan behavioral biases dapat mempengaruhi keputusan investasi pada investor saham. Behavioral biases tidak dapat dipengaruhi oleh karakterstik demografis, sedangkan literasi keuangan dapat mempengaruhi behavioral biases pada investor. Selain itu, behavioral biases tidak dapat memediasi pengaruh karakteristik demografis terhadap keputusan investasi secara tidak langsung, sedangkan behavioral biases dapat memediasi pengaruh literasi keuangan terhadap keputusan investasi secara sebagian (partial mediation).
\end{abstract}

Kata Kunci: Karakteristik Demografis, Literasi Keuangan, Behavioral Biases, Keputusan Investasi

Abstract: This study aims to determine the influence of demographic characteristics and financial literacy on behavioral biases and investment decisions of stock investors, as well as to determine the influence of behavioral biases on investment decisions and the role of behavioral biases in mediating demographic characteristics and financial literacy on investment decisions of stock investors. The research design used in this research is descriptive research with a quantitative approach. This study uses a nonprobability sampling method with a purposive sampling technique. The data collection method used a questionnaire and obtained a sample of 103 respondents. The data analysis technique in this research is Partial Least Square, using SmartPLS software. The results showed that demographic characteristics, financial literacy and behavioral biases can influence investment decisions in stock investors. Behavioral biases cannot be influenced by demographic characteristics, whereas financial literacy can influence behavioral biases in investors. Besides, behavioral biases cannot mediate the influence of demographic characteristics on investment decisions indirectly, but behavioral biases can partially mediate the influence of financial literacy on investment decisions.

Keywords: Demographic Characteristics, Financial Literacy, Behavioral Biases, Investment Decisions 


\section{LATAR BELAKANG}

Saat membuat keputusan investasi, seorang investor akan berusaha mengalokasikan dananya pada instrumen investasi yang dinilainya akan memberikan keuntungan dimasa datang dengan turut mempertimbangkan risiko yang terkandung dari instrumen tersebut. Keberagaman pada karakteristik tiap instrumen investasi akan mempengaruhi sudut pandang investor dalam mengambil keputusan investasi, beberapa di antaranya yaitu Karakteristik Demografis dan Literasi Keuangan. Dalam mempengaruhi keputusan investasi, karakteristik demografis dan literasi keuangan juga dapat mempengaruhi behavioral biases, yang pada akhirnya akan mempengaruhi hasil keputusan investasi. Sehingga, dapat dikatakan bahwa karakteristik demografis dan literasi keuangan dapat mempengaruhi keputusan investasi investor secara langsung, maupun tidak langsung yaitu melalui pengaruh behavioral biases.

Behavioral biases pada investor merupakan faktor psikologi yang dapat mempengaruhi perilaku investor dalam pengambilan keputusan investasi. Ada dua bias yang sering kali dihadapi investor yaitu bias kognitif yang dikarenakan kesalahan dalam pemahaman suatu informasi dan bias emosional yang lebih mengutamakan perasaan dibandingkan fakta (Manulife Asset Management, 2015). Walapun banyak perilaku bias yang dapat mempengaruhi keputusan investasi investor, terdapat satu perilaku bias yang umumnya sering mempengaruhi investor yaitu overconfidence. Overconfidence adalah bias emosional pada perilaku investor, dimana investor terlalu percaya diri dibandingkan investor yang lain, bahwa keputusan investasi yang diambilnya akan menghasilkan pengembalian yang positif. Prosad et al. (2015) memberikan peringkat pada masing-masing bias yang mempengaruhi keputusan investor dan menemukan bahwa overconfidence merupakan bias yang paling umum mempengaruhi investor. Namun dalam penelitian Paramita dkk. (2018) ditemukan bahwa overconfidence tidak berpengaruh terhadap perilaku investor. Adanya perbedaan hasil pada kedua hasil penelitian ini, menarik untuk dilakukan penelitian kembali tentang pengaruh overconfidence pada keputusan investasi.

Karakteristik demografis dapat secara langsung maupun tidak langsung mempengaruhi keputusan investasi investor. Walaupun banyak karakteristik demografis lainnya yang dapat mempengaruhi investor, namun menurut Adioetomo dan Samosir (2010) karakteristik demografis yang paling utama adalah usia dan jenis kelamin. Selain itu dari temuan penelitian sebelumnya terdapat perbedaan hasil penelitian tentang pengaruh usia dan jenis kelamin pada keputusan investasi. Oleh karena itu karakteristik demografis yang akan diteliti adalah usia dan jenis kelamin, guna mengetahui apakah usia dan jenis kelamin dapat mempengaruhi keputusan investasi baik secara langsung maupun tidak langsung yaitu melaui overconfidence sebagai bias perilaku investor. Metawa et al. (2018) menemukan bahwa perbedaan usia tidak memainkan peran penting dalam pengambilan keputusan investasi. Berbeda dengan Prosad et al. (2015) yang berpendapat bahwa usia merupakan faktor yang paling mempengaruhi bias pada investor. Pengaruh karakteristik demografis terhadap keputusan investasi dijelaskan oleh Barber dan Odean (2001) yang melaporkan bahwa pria berinvestasi lebih banyak dari pada wanita. Mereka menyimpulkan bahwa wanita cenderung menghindari risiko, sementara pria terlalu percaya diri dalam mengambil keputusan investasi, yang akhirnya mengarah pada kesalahan yang dapat menimbulkan kerugian. Selain itu, hasil penelitian Prosad et al. (2015) menyatakan bahwa wanita ditemukan kurang percaya diri dan lebih pesimis daripada pria dalam berinvestasi di pasar saham karena mereka berpikir bahwa harga emas akan meningkat dalam waktu dekat dan investor yang berusia tua lebih rentan terhadap perilaku bias dalam membuat keputusan investasi.

Literasi keuangan dimaksudkan sebagai tingkat pemahaman dan pengetahuan akan berbagai instrumen keuangan sehingga dapat membuat keputusan finansial secara optimal dan 
terhindar dari risiko keuangan yang tidak diharapkan. Semakin beragamnya instrumen investasi saat ini, menuntut masyarakat untuk lebih memahami karakteristik dari tiap instrumen. Sebab tiap instrumen investasi mengandung keuntungan dan risiko yang berbeda. Rasool dan Ullah (2019) mengatakan bahwa produk keuangan saat ini sangat kompleks dan mengharuskan investor untuk melek finansial sehingga dapat melakukan keputusan investasi secara optimal. Di Indonesia peningkatan literasi keuangan terus didorong, hal ini terlihat dengan diluncurkannya Strategi Nasional Literasi Keuangan Indonesia (SNLKI). Berdasarkan survei pada tingkat literasi keuangan yang dilakukan Otoritas Jasa Keuangan (OJK) pada 2019 ditemukan bahwa indeks literasi keuangan mencapai 38,03\%, hasil ini meningkat dibandingkan dengan indeks literasi keuangan pada 2016 yaitu 29,7\%. Namun angka ini masih terbilang rendah bila dibandingkan dengan negara lain. Hal ini dapat dikonfirmasi dengan pernyataan Presiden Joko Widodo dalam Tempo pada Januari 2020 yang mengatakan bahwa walaupun tingkat literasi keuangan di Indonesia meningkat, angka ini masih rendah bila dibandingkan dengan negara lain di Asia Tenggara. Maka literasi keuangan dibutuhkan karena keragaman instrumen investasi dan instrumen investasi saham memiliki tingkat risiko yang tinggi, dalam kondisi pasar yang tidak menentu dengan literasi keuangan yang baik investor dapat membuat keputusan investasi yang rasional dan terhindar dari bias perilaku.

Investor yang dimaksud dalam penelitian ini adalah investor yang melakukan investasinya pada pasar saham. Bursa Efek Indonesia dalam Kompas.com mengungkapkan bahwa pada tahun 2019 total investor saham mengalami kenaikan 30\% yaitu 1,10 juta investor dibandingkan tahun 2018 dengan total investor 852.000 investor, dan pada Mei 2020 jumlah investor saham mencapai 1,19 juta investor. Dari persentase jumlah investor saham yang semakin meningkat, terlihat bahwa minat masyarakat terhadap instrumen investasi saham terus meningkat. Maka, penting untuk mengetahui apakah karakteristik demografis dan literasi keuangan dapat mempengaruhi keputusan investasi pada investor saham baik secara langsung, maupun tidak langsung yaitu melalui behavioral biasses.

Tujuan penelitian ini adalah untuk mengetahui mengenai pengaruh karakteristik demografis dan literasi keuangan secara langsung terhadap keputusan investasi, pengaruh karakteristik demografis dan literasi keuangan secara tidak langsung yaitu melalui behavioral biases terhadap keputusan investasi, pengaruh karakteristik demografis dan literasi keuangan terhadap behavioral biases dan pengaruh behavioral biases terhadap keputusan investasi.

Hasil penelitian ini diharapkan dapat memberikan manfaat kepada: Pertama, investor saham di Indonesia yaitu untuk mengetahui pengaruh karakteristik demografis, literasi keuangan dan behavioral biases terhadap keputusan investasinya. Sehingga, dengan mengetahui pengaruh terhadap keputusannya, investor dapat berusaha meminimalisir faktorfaktor negatif yang dapat menurunkan hasil keputusannya. Kedua, bagi penelitian selanjutnya yaitu sebagai sumber informasi dan referensi mengenai penelitian sejenis.

\section{KAJIAN TEORI}

\section{Behavioral Finance}

Behavioral finance muncul sebagai konsep baru yang menggabungkan aspek perilaku dan psikologis dalam pengambilan keputusan ekonomi dan keuangan. Prospect theory sebagai bagian dari behavioral finance menjelaskan bahwa seorang individu dalam mengambil keputusan investasi tidak selalu konsisten memaksimalkan utilitas yang diharapkan, melainkan didasarkan pada potensi keuntungan atau kerugian yang akan dihadapi dan bukan berdasarkan hasil akhir yang akan didapatkan (Kahneman \& Tversky, 1979). Berdasarkan teori prospek dikatakan bahwa investor dalam membuat keputusan investasi tidak selalu rasional dan dapat dipengaruhi oleh bias, seperti bias overconfidence. Jika terdapat dua instrumen investasi yang 
menghasilkan hasil akhir yang sama, namun salah satunya disertai potensi kerugian yang kemudian baru menghasilkan keuntungan. Investor yang berinvestasi pada instrumen yang memiliki potensi keuntungan tanpa disertai potensi kerugian umumnya akan menunjukan bias overconfidence.

\section{Theory of Planned Behavior}

Theory of Planned Behavior oleh Ajzen (1991) dikembangkan untuk memperbaiki kelemahan pada Theory of Reasoned Action, dengan memberikan faktor tambahan yang menentukan keinginan untuk berperilaku yaitu perceived behavioral control. Theory of Planned Behavior dapat menjelaskan mengenai pengaruh literasi keuangan terhadap keputusan investasi. Dalam Theory of Planned Behavior dikemukakan bahwa persepsi control ditentukan oleh keyakinan individu atas ketersedian sumber daya meliputi peralatan, kompatibilitas, kompetensi dan kesempatan yang dapat mendukung atau menghambat perilaku dan besarnya peran sumber daya dalam mewujudkan perilaku. Dalam hal ini literasi keuangan merupakan kompetensi yang dibutuhkan investor untuk dapat membuat keputusan investasi yang rasional. Theory of Planned Behavior mengasumsikan bahwa manusia merupakan makhluk yang rasional, yang akan menggunakan informasi-informasi yang tersedia baginya secara sistematis.

Berikut pengembangan hipotesis penelitian berdasarkan hasil penelitian terdahulu:

\section{Pengaruh Karakteristik Demografis terhadap Keputusan Investasi}

Karakteristik demografis merupakan bidang yang mempelajari tentang populasi manusia di suatu kelompok masyarakat yang besar, sehingga antar individu dapat dibedakan berdasarkan karakteristik-karakteristik tertentu. Berdasarkan usia, Lutfi (2010) mengatakan bahwa pengaruh usia terhadap keputusan investasi yaitu seiring dengan bertambahnya usia, toleransi investor terhadap risiko akan meningkat namun saat mendekati masa pensiun investor akan lebih menghindari risiko. Sedangkan berdasarkan jenis kelamin, Mittal dan Vyas (2011) mengungkapkan wanita umumnya akan lebih berhati-hati dalam mengambil keputusan, dan pria umumnya akan mengambil keputusan investasi dengan cepat dan berisiko.

H1: Karakteristik demografis berpengaruh terhadap keputusan investasi.

\section{Pengaruh Literasi Keuangan terhadap Keputusan Investasi}

Literasi keuangan merupakan pengetahuan dan pemahaman akan instrumen dan lembaga keuangan, sehingga dapat memanfaatkan keterampilannya tersebut untuk mengambil keputusan keuangan dan melakukan pengelolaan keuangan dengan optimal guna meningkatkan kesejahteraan finansial. Dengan literasi keuangan yang baik, investor memiliki pengetahuan dan pemahaman yang memadai untuk meminimalisir risiko dalam investasi saham dengan melakukan diversifikasi portofolio sehingga dapat menghasilkan keputusan investasi yang baik. Awais et al. (2016) melakukan penelitian tentang literasi keuangan dan keputusan investasi di Pakistan dan menemukan bahwa literasi keuangan berpengaruh positif terhadap keputusan investasi.

\section{H2: Literasi keuangan berpengaruh positif terhadap keputusan investasi.}

\section{Pengaruh Karakteristik Demografis terhadap Behavioral Biases}

Perbedaan karakteristik demografis yaitu berdasarkan usia dan jenis kelamin pada investor dapat mempengaruhi bias perilaku yang dihadapi investor. Berdasarkan jenis kelamin, umumnya pria lebih sering terkena bias overconfidence. Hal ini didukung oleh Barber dan Odean (2001) yang menyimpulkan bahwa wanita menghindari risiko, sementara pria terlalu percaya diri (overconfidence). Selain itu Prosad et al. (2015); Baker et al. (2018) juga menemukan bahwa pria lebih percaya diri daripada wanita tentang pengetahuan yang mereka miliki mengenai pasar saham. Sedangkan berdasarkan usia, Tekce et al. (2016) menemukan 
bahwa overconfidence di antara investor individu akan menurun seiring dengan bertambahnya usia.

H3: Karakteristik demografis berpengaruh terhadap behavioral biases.

\section{Pengaruh Literasi Keuangan terhadap Behavioral Biases}

Overconfidence merupakan bias emosional yang disebabkan rasa kepercayaan diri yang berlebihan akan informasi dan ketepatan hasil prediksi yang pernah dicapainya. Rasa percaya diri yang berlebihan ini tidak disertai dengan literasi keuangan yang baik, sehingga dalam berperilaku investor menjadi tidak rasional karena cenderung mengabaikan fakta dan hanya mengikuti perasaannya saja. Dengan literasi keuangan yang baik, behavioral biases seperti overconfidence dapat diminimalisir. Rasool dan Ullah (2019) mengatakan bahwa terdapat hubungan negatif yang kuat antara literasi keuangan dengan behavioral biases pada individu.

\section{H4: Literasi keuangan berpengaruh negatif terhadap behavioral biases.}

\section{Pengaruh Behavioral Biases terhadap Keputusan Investasi}

Investor dituntut untuk rasional saat membuat keputusan investasi, namun nyatanya bias-bias ini sulit dihindari sehingga mempengaruhi perilaku investor dalam berinvestasi. Adanya faktor psikologi membuat keputusan investasi investor menyimpang dikarenakan investor cenderung tidak mempertimbangkan fakta yang sebenarnya terjadi dan mengabaikan informasi yang tersedia, sehingga mengambil keputusan berdasarkan perasaannya. Investor menjadi terlalu percaya diri pada informasi dan kemampuan yang dimilikinya, khususnya pada investor yang terkena bias overconfidence. Paramita dkk. (2018) mengatakan kepercayaan diri yang berlebihan dapat membuat investor melakukan transaksi saham yang berlebihan, sehingga return portofolio yang didapat lebih rendah.

H5: Behavioral biases berpengaruh negatif terhadap keputusan investasi.

\section{Pengaruh Karakteristik Demografis terhadap Keputusan Investasi melalui Behavioral Biases}

Secara tidak langsung, karakteristik demografis akan mempengaruhi keputusan investasi melalui behavioral biases yaitu bias overconfidence. Melalui behavioral biases, karakteristik demografis yaitu pria cenderung lebih berani dalam mengambil keputusan investasi. Hal ini membuat pria seringkali terkena bias overconfidence dalam berinvestasi dibandingkan wanita. Sehingga investor pria lebih sering ditemukan membuat kesalahan dalam berinvestasi dengan membuat keputusan investasi pada instrumen investasi yang berisiko tinggi seperti saham secara berlebihan. Sedangkan usia, investor dengan usia muda cenderung tidak menghindari risiko sehingga seringkali mengarahkan mereka terhadap bias overconfidence, sehingga mendorong investor melakukan keputusan investasi yang tidak rasional. Metawa et al. (2018) menunjukan bahwa melalui bias perilaku, karakteristik demografis mempengaruhi bias perilaku investor dalam melakukan keputusan investasi.

H6: Karakteristik demografis berpengaruh terhadap keputusan investasi melalui behavioral biases.

\section{Pengaruh Literasi Keuangan terhadap Keputusan Investasi melalui Behavioral Biases}

Investor dengan literasi keuangan yang baik cenderung membuat investor membuat keputusan investasi secara rasional, ia akan membuat keputusan berdasarkan informasi atau fakta yang ada dan bukan mendasarkan pada perasaannya semata. Sehingga, bias yang dialami investor akan berkurang dengan tingkat pengetahuan dan pemahaman yang baik akan pengelolaan keuangan. Humairo (2020) dalam penelitiannya juga menemukan bahwa secara 
tidak langsung literasi keuangan memiliki pengaruh positif terhadap keputusan investasi saham melalui bias perilaku.

H7: Literasi keuangan berpengaruh positif terhadap keputusan investasi melalui behavioral biases.

Berdasarkan uraian diatas, maka model penelitian adalah seperti berikut:

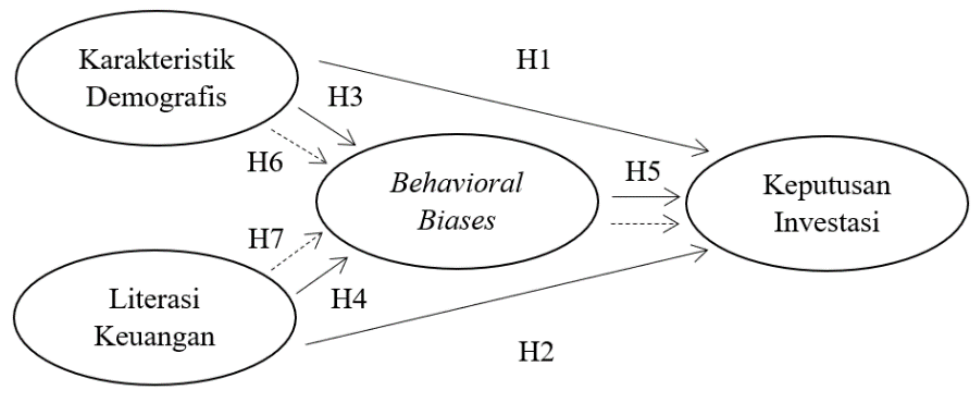

Gambar 1. Model Penelitian

\section{METODOLOGI}

Desain penelitian yang digunakan dalam penelitan ini adalah penelitian deskriptif dengan pendekatan kuantitatif. Data yang yang digunakan adalah data primer, dengan kuesioner menjadi metode pengumpulan data. Populasi dalam penelitian ini adalah investor saham di Indonesia. Teknik pemilihan sampel yang digunakan dalam penelitian ini adalah nonprobability sampling yaitu purposive sampling, dengan kriteria yang ditetapkan untuk penentuan sampel yaitu investor saham di Indonesia yang sudah melakukan transaksi jual atau beli saham dengan pengalaman investasi minimal enam bulan. Jumlah responden diperoleh adalah 103 responden yang merupakan investor saham di Indonesia dengan pengalaman investasi saham minimal enam bulan dan 11 responden tidak memenuhi kriteria sampel. Sehingga yang menjadi unit analisis dalam penelitian ini adalah 103 responden yang memenuhi kriteria sampel yang ditetapkan.

Dalam penelitian ini, terdapat dua variabel independen yaitu karakteristik demografis dan literasi keuangan yang mempengaruhi satu variabel dependen yaitu keputusan investasi, dengan satu variabel mediasi yaitu behavioral biases yang menengahi hubungan antara variabel independen dan variabel dependen. Pengukuran variabel karakteristik demografis diukur menggunakan skala nominal untuk jenis kelamin dan skala rasio untuk usia. Sedangkan keputusan investasi, literasi keuangan dan behavioral biases dalam penelitian ini diukur menggunakan skala likert. Skala likert yang digunakan merupakan 5-Point Likert Scale dengan angka 1 menyatakan sangat tidak setuju dan angka 5 menyatakan sangat setuju.

Tabel 1. Operasionalisasi Variabel

\begin{tabular}{|c|c|c|c|c|}
\hline Variabel & Acuan & Indikator & Item & Skala \\
\hline \multirow{2}{*}{$\begin{array}{c}\text { Karakteristik } \\
\text { Demografis }\end{array}$} & \multirow{2}{*}{$\begin{array}{l}\text { Metawa, N. M. K. } \\
\text { H., Metawa, S., \& } \\
\text { Safa, M. F. (2018) }\end{array}$} & Jenis Kelamin & 2 item & Nominal \\
\hline & & Usia & 2 item & Rasio \\
\hline & & General Knowledge & 4 item & \multirow[b]{2}{*}{ Likert } \\
\hline & & Saving \& Borrowing & 4 item & \\
\hline
\end{tabular}




\begin{tabular}{|c|c|c|c|c|}
\hline \multirow{2}{*}{$\begin{array}{c}\text { Literasi } \\
\text { Keuangan }\end{array}$} & \multirow{2}{*}{$\begin{array}{l}\text { Chen, H. \& Volpe, } \\
\text { R. P. (1998) }\end{array}$} & Insurance & 4 item & \\
\hline & & Investment & 4 item & \\
\hline $\begin{array}{c}\text { Behavioral } \\
\text { Biases }\end{array}$ & $\begin{array}{l}\text { Metawa, N. M. K. } \\
\text { H., Metawa, S., \& } \\
\text { Safa, M. F. (2018) }\end{array}$ & Overconfidence & 5 item & Likert \\
\hline \multirow{2}{*}{$\begin{array}{c}\text { Keputusan } \\
\text { Investasi }\end{array}$} & \multirow{2}{*}{$\begin{array}{l}\text { Metawa, N. M. K. } \\
\text { H., Metawa, S., \& } \\
\text { Safa, M. F. (2018) }\end{array}$} & Fundamental Analysis & 3 item & \multirow{2}{*}{ Likert } \\
\hline & & Technical Analysis & 7 item & \\
\hline
\end{tabular}

Analisis data yang digunakan adalah Partial Least Square (PLS) dengan software SmartPLS 3.0. Analisis PLS terdiri dari dua model yaitu model pengukuran dan model struktural. Model pengukuran (outer model) dievaluasi untuk mengetahui bagaimana setiap indikator berhubungan dengan variabel latennya, sehingga dilakukan dengan menguji validitas dan reliabilitas pada indikator variabel penelitian (Abdillah \& Hartono, 2015). Uji validitas terdiri dari validitas konvergen dan validitas diskriminan. Uji validitas konvergen diukur dengan nilai Average Variance Extracted (AVE) >0,5 dan outer loading >0,5 (Ghozali \& Latan, 2015). Uji validitas diskriminan dapat diukur dengan nilai cross loadings, yaitu dengan membandingkan nilai loading suatu indikator harus lebih besar dibandingkan dengan nilai loading indikator lain. Uji reliabilitas dilakukan dengan menggunakan composite reliability dengan nilai composite reliability >0,7 (Ghozali \& Latan, 2015).

Model struktural (inner model) digunakan untuk menunjukkan kekuatan estimasi antar variabel laten. Model struktural dievaluasi dengan menggunakan $R$ Square $\left(\mathrm{R}^{2}\right), Q$ Square Predictive Relevance $\left(\mathrm{Q}^{2}\right)$, effect size $\left(\mathrm{f}^{2}\right)$, dan path coefficients untuk uji pengaruh langsung dan indirect effects untuk uji pengaruh tidak langsung. Path coefficients dan indirect effects untuk pengujian hipotesis bertujuan menggambarkan hubungan antar variabel dengan melihat nilai $t$-statistics $>1,96$ dan $p$-values $<0,05$ dengan alpha $5 \%$.

\section{HASIL ANALISIS DATA}

\section{Evaluasi Model Pengukuran (outer model)}

Analisis model pengukuran (outer model) dilakukan dengan uji validitas dan uji reliabilitas. Berdasarkan hasil analisis model pengukuran, ditemukan bahwa indikator yang digunakan untuk mengukur variabel-variabel penelitian bersifat valid dan reliabel setelah dilakukan penghapusan terhadap 1 item pada literasi keuangan dan 1 item pada behavioral biases, sehingga indikator dapat mempresentasikan variabel penelitian dan dapat dipercaya serta diandalkan.

\section{Evaluasi Model Struktural (inner model)}

Model struktural dievaluasi dengan menggunakan $R$ Square $\left(\mathrm{R}^{2}\right), Q$ Square Predictive Relevance $\left(\mathrm{Q}^{2}\right)$, effect size $\left(\mathrm{f}^{2}\right)$, path coefficients, dan indirect effects.

Tabel 2. Nilai $R$-Square dan $Q$-Square

\begin{tabular}{|c|c|c|}
\hline \multicolumn{2}{|c|}{$R$-Square } & \multirow{2}{*}{$Q$-Square } \\
\hline Behavioral Biases & Keputusan Investasi & \\
\hline 0,815 & 0,874 & 0,977 \\
\hline
\end{tabular}

Berdasarkan tabel 2 nilai $R$-Square menunjukkan bahwa variabel independen dapat menjelaskan variabel behavioral biases sebesar $81,5 \%$, sedangkan sisanya dapat dijelaskan 
oleh variabel lain. Selain itu variabel independen dan mediasi dapat menjelaskan variabel keputusan investasi sebesar $87,4 \%$, sedangkan sisanya dapat dijelaskan oleh variabel lain. Nilai $Q$-Square 0,977 > 0 menunjukan bahwa model memiliki predictive relevance. Sehingga, hal ini memberikan kesimpulan bahwa variabel karakteristik demografis, literasi keuangan dan behavioral biases memiliki tingkat prediksi yang baik terhadap keputusan investasi. Selain itu, evaluasi model struktural juga dapat dilakukan melalui effect size $\left(\mathrm{f}^{2}\right)$.

\section{Tabel 3. Nilai Effect Size $\left(\mathrm{f}^{2}\right)$}

\begin{tabular}{|l|c|c|}
\hline & Behavioral Biases & Keputusan Investasi \\
\hline Behavioral Biases & & 0,093 \\
\hline Karakteristik Demografis & 0,030 & 0,094 \\
\hline Literasi Keuangan & 0,659 & 0,233 \\
\hline Keputusan Investasi & & \\
\hline
\end{tabular}

Berdasarkan tabel 3 menunjukkan bahwa karakteristik demografis terhadap behavioral biases mempunyai pengaruh kecil, literasi keuangan terhadap behavioral biases mempunyai pengaruh besar, behavioral biases terhadap keputusan investasi memiliki pengaruh kecil, karakteristik demografis terhadap keputusan investasi memiliki pengaruh kecil, dan literasi keuangan terhadap keputusan investasi memiliki penharuh menengah. Uji hipotesis yaitu uji pengaruh langsung melalui path coefficients dan uji pengaruh tidak langsung melalui indirect effects, menemukan hasil sebagai berikut:

Tabel 4. Hasil Path Coefficients dan Indirect Effects

\begin{tabular}{|c|c|c|c|c|c|}
\hline \multirow{4}{*}{$\begin{array}{c}\text { Path } \\
\text { Coefficients }\end{array}$} & $\begin{array}{c}\text { Hubungan } \\
\text { Antar Variabel }\end{array}$ & $\begin{array}{c}\text { Original } \\
\text { Sample }(O)\end{array}$ & T Statistics & P Values & Kesimpulan \\
\cline { 2 - 6 } & $\mathrm{X} 1 \rightarrow \mathrm{Y}$ & 0,240 & 4,042 & 0,000 & Hipotesis Diterima \\
\cline { 2 - 6 } & $\mathrm{X} 2 \rightarrow \mathrm{Y}$ & 0,479 & 4,385 & 0,000 & Hipotesis Diterima \\
\cline { 2 - 6 } & $\mathrm{X} 1 \rightarrow \mathrm{M}$ & $-0,161$ & 1,599 & 0,111 & Hipotesis Ditolak \\
\cline { 2 - 6 } & $\mathrm{X} 2 \rightarrow \mathrm{M}$ & $-0,757$ & 7,937 & 0,000 & Hipotesis Diterima \\
\cline { 2 - 6 } Indirect & $\mathrm{X} 1 \rightarrow \mathrm{Y}$ & $-0,253$ & 3,239 & 0,001 & Hipotesis Diterima \\
\cline { 2 - 6 } Effects & $\mathrm{X} 2 \rightarrow \mathrm{M} \rightarrow \mathrm{Y}$ & 0,041 & 1,405 & 0,162 & Hipotesis Ditolak \\
\hline
\end{tabular}

\section{DISKUSI}

Hipotesis pertama diterima dan dinyatakan bahwa karakteristik demografis secara langsung dapat mempengaruhi keputusan investasi. Usia investor mempengaruhi investor saham dalam pengambilan keputusan investasi. Hal ini dikarenakan perbedaan usia mempengaruhi penilaian investor terhadap risiko dan mempengaruhi hal yang menjadi pertimbangan investor sebelum melakukan investasi. Jenis kelamin juga mempengaruhi pengambilan keputusan investasi, investor pria cenderung mengabaikan risiko dan lebih berani dalam mengambil keputusan investasi pada instrumen investasi yang mengandung risiko tinggi seperti saham. Sedangkan wanita cenderung menghindari risiko dan ketidakpastian, wanita lebih suka membuat suatu keputusan investasi pada instrumen investasi yang tidak berfluktuasi dan memberikan return yang lebih pasti. Hasil penelitian ini sejalan dengan penelitian Mittal 
dan Vyas (2011); (Lutfi, 2010); yang menemukan pengaruh karakteristik demografis terhadap keputusan investasi.

Hipotesis kedua diterima, sehingga dinyatakan literasi keuangan berpengaruh positif terhadap keputusan investasi. Dimana peningkatan literasi keuangan pada investor saham juga akan meningkatkan hasil keputusan investasi. Untuk berinvestasi pada instrumen yang mengandung risiko tinggi seperti saham dibutuhkan pengetahuan dan keterampilanketerampilan yang berguna untuk meminimalisir risiko. Theory of Planned Behavior oleh Ajzen (1991) menjelaskan bahwa keinginan untuk berperilaku ditentukan ketersedian sumber daya, salah satunya yaitu kompetensi dan seberapa besar peran sumber daya tersebut dalam mewujudkan perilaku. Dalam hal ini, literasi keuangan merupakan kompetensi yang dibutuhkan oleh investor sehingga mempengaruhi perilaku investor dalam membuat keputusan investasi. Hasil penelitian ini sejalan dengan penelitian Awais et al. (2016); Pertiwi (2018) yang menemukan bahwa literasi keuangan berpengaruh positif terhadap keputusan investasi.

Hipotesis ketiga ditolak, maka dinyatakan bahwa karakteristik demografis yaitu usia dan jenis kelamin tidak mempengaruhi behaviorial biases yaitu overconfidence pada investor saham. Tiap investor memiliki bias yang akan mempengaruhi perilakunya dan sulit menghindar dari bias tersebut, tak terbatas pada usia dan jenis kelamin tertentu. Sesuai dengan pendapat Kahneman dan Tversky (1979) dalam Prospect's Theory yaitu investor tidak rasional dan sulit terhindar dari bias perilaku. Hasil penelitian ini sejalan dengan penelitian Firah (2017); Humairo (2020) yang menemukan bahwa faktor demografi tidak mempengaruhi overconfidence pada investor.

Hipotesis keempat diterima dan dinyatakan bahwa literasi keuangan berpengaruh negatif terhadap behavioral biases, yaitu semakin meningkat literasi keuangan yang dimiliki investor saham akan mengurangi behavioral biases pada investor saham. Literasi keuangan yang baik dapat mengatasi bias overconfidence pada investor saham. Theory of Planned Behavior oleh Ajzen (1991) mengungkapkan bahwa manusia merupakan makhluk yang rasional dalam menggunakan informasi yang tersedia baginya. Maka teori ini dapat menjelaskan bahwa meningkatnya literasi keuangan akan mengurangi bias yaitu overconfidence pada investor. Hasil penelitian ini sejalan dengan penelitian Takeda et al. (2013); Rasool dan Ullah (2019); Humairo (2020) yang mengatakan bahwa terdapat hubungan negatif antara literasi keuangan dengan behavioral biases pada investor.

Hipotesis kelima diterima dan dinyatakan bahwa behavioral biases berpengaruh negatif terhadap keputusan investasi. Behavioral biases yang dimaksud adalah bias overconfidence. Sehingga semakin meningkat bias overconfidence pada investor saham, maka akan membuat keputusan investasi menurun. Overconfidence menyebabkan investor menjadi tidak rasional dalam berinvestasi dikarenakan investor lebih mengutamakan perasaannya dalam membuat keputusan dan menjadi cenderung tidak mempertimbangkan fakta dan informasi yang sebenarnya. Behavioral finance muncul sebagai konsep yang menggabungkan aspek perilaku dan psikologis dalam pengambilan keputusan ekonomi dan keuangan yang berusaha menjelaskan mengenai perilaku investor yang dapat melibatkan hal-hal emosional sehingga mempengaruhi proses pengambilan keputusan. Hasil penelitian ini sejalan dengan penelitian Puspitasari (2014); Bhandari dan Deaves (2006); Gupta dan Banik (2013) yang menemukan pengaruh negatif behavioral biases terhadap keputusan investasi.

Hipotesis keenam ditolak maka dinyatakan bahwa behavioral biases tidak dapat memediasi pengaruh karakteristik demografis terhadap keputusan investasi. Secara tidak langsung karakteristik demografis yaitu usia dan jenis kelamin tidak dapat mempengaruhi keputusan investasi melalui overconfidence sebagai behavioral biases dikarenakan perbedaan usia maupun jenis kelamin diantara investor saham tidak mempengaruhi behavioral biases pada investor, yang pada akhirnya tidak ada perbedaan hasil keputusan investasi. Tiap investor 
saham rentan terhadap bias yang akan mempengaruhi perilakunya dalam mengambil keputusan investasi. Investor sulit menghindar dari bias tersebut, tak terbatas pada usia dan jenis kelamin tertentu. Sesuai dengan pendapat Kahneman dan Tversky (1979) yaitu investor tidak rasional dan sulit terhindar dari bias perilaku. Hasil penelitian ini sejalan dengan penelitian Humairo (2020); Metawa et al. (2018) yang menemukan bahwa behavioral biases tidak mampu memediasi pengaruh karakteristik demografi terhadap keputusan investasi saham.

Hipotesis ketujuh diterima dan dinyatakan bahwa behavioral biases dapat memediasi pengaruh literasi keuangan terhadap keputusan investasi secara positif. Selain itu, dari nilai total effect ditemukan bahwa behavioral biases memediasi pengaruh literasi keuangan terhadap keputusan investasi secara sebagian (partial mediation), yang artinya literasi keuangan tetap mampu mempengaruhi keputusan investasi tanpa melibatkan overconfidence. Theory of Planned Behavior oleh Ajzen (1991) mengungkapkan bahwa keinginan untuk berperilaku ditentukan oleh ketersedian kompetensi. Maka, keinginan untuk berperilaku yaitu keputusan investasi akan ditentukan oleh kompetensi yang dimiliki, yaitu literasi keuangan. Selain itu, Theory of Planned Behavior juga mengungkapkan bahwa manusia merupakan makhluk yang rasional dalam menggunakan informasi yang tersedia baginya. Maka dengan literasi keuangan yang baik, bias overconfidence dapat dikurangi dan investor saham dapat mengambil keputusan investasi secara rasional. Hasil penelitian ini sejalan dengan penelitian Humairo (2020) yang menemukan pengaruh tidak langsung literasi keuangan terhadap keputusan investasi saham melalui bias perilaku.

\section{PENUTUP}

Berdasarkan hasil penelitian menunjukkan bahwa karakteristik demografis, literasi keuangan dan behavioral biases dapat mempengaruhi keputusan investasi pada investor saham. Behavioral biases tidak dapat dipengaruhi oleh karakterstik demografis, sedangkan literasi keuangan dapat mempengaruhi behavioral biases pada investor. Selain itu, behavioral biases tidak dapat memediasi pengaruh karakteristik demografis terhadap keputusan investasi secara tidak langsung, namun behavioral biases dapat memediasi pengaruh literasi keuangan terhadap keputusan investasi secara sebagian.

Peneliti menyadari bahwa penelitian ini memiliki beberapa keterbatasan, yaitu: Pertama, masih terdapat faktor lain yang dapat mempengaruhi keputusan investasi selain karakteristik demografis, literasi keuangan dan behavioral biases. Kedua, penelitian ini hanya mengamati karakteristik demografis yaitu usia dan jenis kelamin, serta behavioral biases yaitu overconfidence. Ketiga, jumlah responden yang diperoleh masih terbilang kecil untuk menggambarkan seluruh keadaan yang sesungguhnya.

Maka berdasarkan keterbatasan tersebut, beberapa saran yang dapat diberikan untuk penelitian selanjutnya yaitu untuk mengamati faktor lain yang dapat mempengaruhi keputusan investasi. Peneliti juga dapat menambah karakteristik demografis dan behavioral biases lainnya yang dapat mempengaruhi keputusan investasi saham. Serta, peneliti dapat menambah jumlah responden untuk menggambarkan pengaruh antar variabel dengan lebih baik.

\section{DAFTAR PUSTAKA}

Abdillah, W. \& Hartono, J. (2015). Partial Least Square (PLS) Alternatif Structural Equation Modeling (SEM) dalam Penelitian Bisnis. Yogyakarta: Andi Offset.

Adioetomo, S. M., \& Samosir, O. B. (2010). Dasar-dasar Demografi. Jakarta: Salemba Empat. Ajzen, I. (1991). The Theory of Planned Behavior. Organizational behavior and human decision processes, 50(2), 179-211. 
Awais, M., Laber, F., Rasheed, N. \& Khursheed, A (2016). Impact of Financial Literacy and Investment Experience on Risk Tolerance and Investment Decisions: Empirical Evidence from Pakistan. International Journal of Economics and Financial Issues, 6(1), 73-79.

Baker, H.K., Kumar, S., Goyal, N. \& Gaur, V. (2018). How financial literacy and demographic variables relate to behavioral biases. Managerial Finance, 45(1), 124-146.

Barber, B. \& Odean, T. (2001). Boys will be boys: gender, overconfidence and common stock investment. The Quarterly Journal of Economics, 116(1), 261-292.

Bhandari, G. \& Deaves, R. (2005). The Demographics of Overconfidence. The Journal of Behavioral Finance, 7(1), 5-11.

Firah, A. (2017). Pengaruh Faktor Demografi Terhadap Kompetensi Dan Overconfidence Investor Serta Keputusan Investasi Investor Saham Di Kota Medan. Tesis. Universitas Sumatera Utara.

Ghozali, I. \& Latan, D. H. (2015). Partial Least Square Konsep, Teknik, dan Aplikasi Menggunakan Program SmartPLS 3.0 (Edisi ke-2). Universitas Diponegoro: Badan Penerbit.

Gupta, A. D. \& Banik. S. (2013). Investors' Psychological Biases Toward Stock Market Investment with Special Reference to Bangladesh. International Journal of Business Insights and Transformation, 6(2), 38-43.

Humairo, N. (2020). Pengaruh Literasi Keuangan dan Faktor Sosiodemografi terhadap Keputusan Investasi Saham dengan Bias Perilaku sebagai Variabel Intervening. Skripsi. Universitas Islam Negeri, Malang.

Kahneman, D. \& Tversky, A. (1979). Prospect theory: An analysis of decision under risk. Econometrica, 47(2), 263-291.

Kompas. (2020) Sepanjang 2019, Jumlah Investor Pasar Modal Indonesia Tembus 2,48 Juta. (Retrieved from: www.kompas.com/24-9-2020)

Lutfi. (2010). The Relationship Between Demographic Factors and Investment Decision in Surabaya. Journal of Economics, Business and Accountancy Ventura, 13(3), 213-224.

Manulife Asset Management (2015). Behavioral Finance: Kognisi \& Emosi dalam Berinvestasi. Manulife Asset Management, 27(Oktober), 1-2.

Metawa, N., Hassan, M. K., Metawa, S., \& Safa, M. F. (2018). Impact of behavioral factors on investors' financial decisions: case of the Egyptian stock market. International Journal of Islamic and Middle Eastern Finance and Management, 12(1), 30-55.

Mittal, M., \& Vyas, R. (2011). A Study of Psychological Reasons for Gender Differences in Preferences for Risk and Investment Decisions Making. The IUP Journal of Behavioral Finance, 8(3), 45-50.

Otoritas Jasa Keuangan (2019). Siaran Pers Survei OJK 2019: Indeks Literasi dan Inklusi Keuangan Meningkat, Otoritas Jasa Keuangan, 58(11).

Paramita, RA. S., Isbanah, Y. \& Purwohandoko (2018). Bias Kognitif dan Kepribadian Individu: Studi Perilaku Investor Muda di Surabaya. Jurnal Riset Manajemen Sains Indonesia, 9(2), 214-235.

Pertiwi, M. M. (2018). Pengaruh Finance Literacy dan Faktor Demografi terhadap Keputusan Investasi Mahasiswa. Skripsi. Universitas Islam Indonesia, Yogyakarta.

Prosad, J.M., Kapoor, S. \& Sengupta, J. (2015). Behavioral biases of Indian investors: a survey of Delhi-NCR region. Qualitative Research in Financial Markets, 7(3), 230-263.

Puspitasari, P. N. (2014). Pengaruh Faktor Demografi dan Faktor Psikologis terhadap Pengambilan Keputusan Investasi pada Reksadana. Sekolah Tinggi Ilmu Ekonomi Perbanas Surabaya. 
Rasool, N. \& Ullah, S. (2019). Financial literacy and behavioural biases of individual investors: empirical evidence of Pakistan stock exchange. Journal of Economics, Finance and Administrative Science, 20(May), 1-15.

Takeda, K., Takemura, T. \& Kozu, T. (2013). Investment literacy and individual investor biases: survey evidence in the Japanese stock market. Review of Socionetwork Strategies, 7(1), 31-42.

Tekce, B., Y1lmaz, N. \& Bildik, R. (2016). What factors affect behavioral biases? Evidence from Turkish individual stock investors. Research in International Business and Finance, 37, 515-526.

Tempo. (2020) Jokowi Akui Literasi dan Inklusi Keuangan Masih Rendah. (Retrieved from: koran.tempo.co/15-9-2020) 